\title{
Microstructure and Strength of Titanium After Heat Treatment at Different Temperatures in the Range of $680-1000^{\circ} \mathrm{C}$
}

\author{
Xingyu Zhang ${ }^{1, \text { * }}$, Benjamin Hanes ${ }^{2}$, Daniel Brooks ${ }^{2}$, Steve Niezgoda ${ }^{2}$, * \\ ${ }^{1}$ Department of Materials Science and Engineering, University of Pennsylvania, Philadelphia, USA \\ ${ }^{2}$ Department of Materials Science and Engineering, The Ohio State University, Columbus, USA \\ Email address: \\ Xingyu5422@gmail.com (Xingyu Zhang), benjaminhanes@mac.com (B. Hanes), dlbrooks95@gmail.com (D. Brooks), \\ niezgoda.6@osu.edu (S. Niezgoda) \\ ${ }^{*}$ Corresponding author
}

\section{To cite this article:}

Xingyu Zhang, Benjamin Hanes, Daniel Brooks, Steve Niezgoda. Microstructure and Strength of Titanium After Heat Treatment at Different Temperatures in the Range of $680-1000^{\circ}$ C. International Journal of Materials Science and Applications. Vol. 8, No. 3, 2019 , pp. 47-55. doi: $10.11648 /$ j.ijmsa.20190803.13

Received: July 18, 2019; Accepted: August 26, 2019; Published: August 27, 2019

\begin{abstract}
The main purpose of this research is to determine the effect of brazing treatment on mechanical properties of both titanium Grade 2 and titanium Grade 5 alloys. The research group obtained Grade 2 and Grade 5 titanium alloys and brazingtreated them at temperatures of $680,800,850,900,920,950$, and $1000^{\circ} \mathrm{C}$. Afterward, each sample was tensile tested, mounted, hardness tested, and observed by optical microscope to investigate corresponding microstructures. Based on the result sheets, it was revealed that the yield strength and tensile strength and ultimate strength of Ti Grade 2 alloys showed drastic fall after heating to $680^{\circ} \mathrm{C}$, then no change up to $850^{\circ} \mathrm{C}$, fall again up to $950^{\circ} \mathrm{C}$, and remained unchanged strength to $1000^{\circ} \mathrm{C}$ However, the Ti Grade 5 samples showed completely different behavior. The yield strength was unchanged after heating to different temperatures. When heating to $680^{\circ} \mathrm{C}$. It didn't affect the strength at all, then after heating to $800^{\circ} \mathrm{C}$, the strength decreased about $100 \mathrm{MPa}$. But after this, higher temperatures didn't change strength anymore. The Ultimate strength however showed a different trend as it continuously went down at elevated temperature. Meanwhile, the hardness of both alloys decreased constantly when temperature increased. Regarding Ti Grade 2 alloys, the initial drop in strength was due to annealing. Around $800^{\circ} \mathrm{C}$, alpha laths started to form and that caused strength to increase. When the temperature reached at $850^{\circ} \mathrm{C}$, the basketweave alpha laths were formed. Over that temperature, the grain sizes were significantly large which caused the strength to decrease. However, there was not much of change in alpha/beta ratio for Ti Grade 5 alloys. EBSD could be a helpful method since the alpha grain size can be determined from that.
\end{abstract}

Keywords: Titanium Alloys, Brazing, Microstructures, Mechanical Properties

\section{Introduction}

Brazing is a metal-joining process that puts two or more metals together by melting and flowing a filler metal into the joint. Brazing has many advantages over other techniques. For instance, brazing could provide a clean joint without the need of secondary finishing. Meanwhile, it produces less thermal distortion than welding. An example of brazed interface of titanium is presented at Figure 1. Also, there would be a thermal cycle for brazed area. The following Figure (Figure 2) shows an example of brazing thermal cycles [1]. Braze alloy is generally available as rod, powder, paste, cream and so on [2]. Some common types of filler metals used are Aluminum-silicon, Copper-silver, Copper-zinc (brass), Copper-tin (bronze), Gold-Silver, Nickel alloy, Silver [3]. Among all types of base alloys, titanium alloys are a hot metallic material because of its high strength and toughness. It can be classified into four categories, which are alpha alloys, near-alpha alloys, alpha and beta alloys and beta and near beta alloys $[4,5]$. By working as well as heat treated them below or above the alpha-beta transition temperature, a large change in microstructure can be achieved. Therefore, this would 
significantly improve the strength of material. The transition temperature is different for distinctive titanium grades. Microstructure of Titanium Grade 2 joint brazed in vacuum at $1180^{\circ} \mathrm{C}$, Ni-27 Ti-10Al filler metal can be seen in Figure 1, and Figure 2 shows an example of Titanium Brazing thermal cycle [1]. It is important to mention that the most commonly used titanium alloy is Grade 5 which is known as Ti6Al4V. It has a chemical composition of $6 \%$ aluminum, $4 \%$ vanadium, $0.25 \%$ (maximum) iron, $0.2 \%$ (maximum) oxygen, and the remainder titanium. The application of this kind of alloys includes blades, discs, rings, airframes, fasteners, components, vessels, cases, hub $[6,7]$.

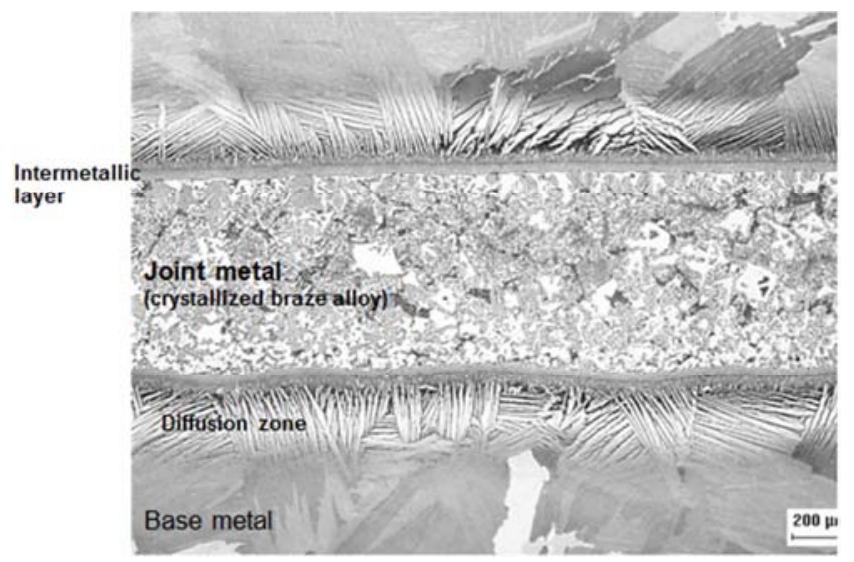

Figure 1. Microstructure of Titanium Grade 2 joint brazed in vacuum at $1180^{\circ} \mathrm{C}, \mathrm{Ni}-27 \mathrm{Ti}-10 \mathrm{Al}$ filler metal [1].

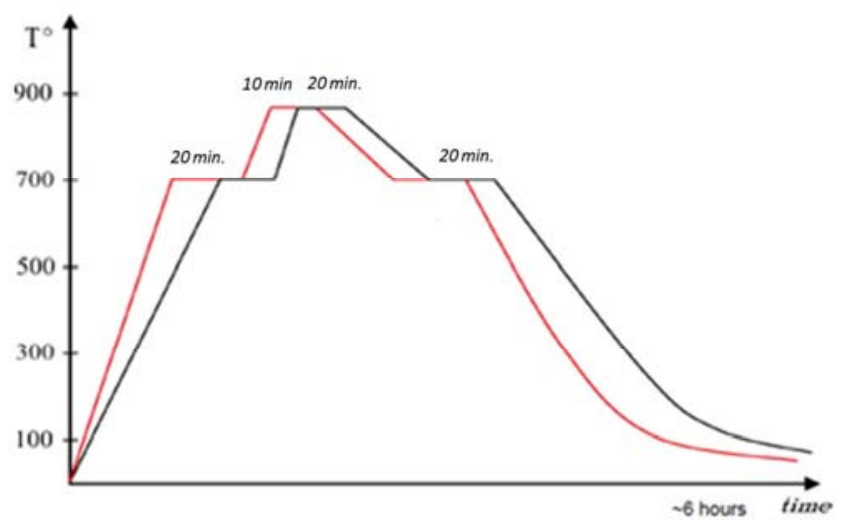

Figure 2. An example of Titanium Brazing thermal cycle [1].

In previous research, Scientists tried to investigate several titanium related brazing systems. Some notable publishes included the correlation between the mechanical properties and the microstructural behavior of $\mathrm{Al}_{2} \mathrm{O}_{3}-(\mathrm{Ag}-\mathrm{Cu}-\mathrm{Ti})$ brazed joint [8]. A range of temperature from $800^{\circ} \mathrm{C}$ to $1200^{\circ} \mathrm{C}$ was tested. Also, Scientist tried to reveal the mechanism of Ti/Al dissimilar alloys. Their brazing zone was examined under transmission electron microscope (TEM). A composition difference in different zone and a clear stacking fault structure in intermetallic phase $\mathrm{TiAl}_{3}$ was discovered [9]. Also, it was demonstrated Grade 7 and Grade 5 titanium alloys which were brazed by $25 \mathrm{Ti}-25 \mathrm{Zr}-50 \mathrm{Cu}$ brazing foil. The mechanical properties around brazing zone were tested and it was found out that fast cooling rate after brazing could suppress formation of the brittle phase, thus resulting in high mechanical properties of the brazed joint [10]. Speaking of more recent studies about titanium alloys brazing, a study revealed a novel multicomponent Ti50-Zr27-Cu8-Ni4-Co3-Fe2-Al3-Sn2-Si1 (at. \%) amorphous brazing filler metals with low content of $\mathrm{Cu}$ and $\mathrm{Ni}$ and low liquidus temperature was designed and synthesized by melt spinning. When brazed with Grade 5 titanium alloys, high shear strength was exhibited around brazing zone [11]. A. Winiowski and D. Majewski also presented a study by brazing of Grade 2 titanium with 6082 aluminum alloy using B-Ag72-Cu28 grade silver brazing metal as an interlayer. Then shear strength and microstructures of brazed joints were studied and it was obtained that the highest quality of the sample was that brazed at $530^{\circ} \mathrm{C}$ with a 30 -minute hold [12].

From those literature reviews, it was discovered that majority of papers focused on the properties at brazing zones, and none of them focus on the metal alloys as a whole. It is significant to know the change of titanium strength due to the effect of a brazing thermal cycle in order to evaluate its effect on reliability of brazed structures. However, a systematic study of the strength of titanium base metals after brazing and auxiliary heat treatment was not done yet. Therefore, our research group investigated how heat treatment in terms of brazing will affect the mechanical properties of titanium alloys and how they were changed at different temperatures (from $680^{\circ} \mathrm{C}$ to $1000^{\circ} \mathrm{C}$ ).

The main objective of this project is to determine the effects the brazing process would have on the mechanical properties and microstructures of both Grade 2 and Grade 5 Titanium alloys. The group conducts mechanical testing of two types of alloys after heat treatment at $680^{\circ} \mathrm{C}, 850^{\circ} \mathrm{C}, 900^{\circ} \mathrm{C}, 950^{\circ} \mathrm{C}$ and $1000^{\circ} \mathrm{C}$ accordingly. Then, each of the samples is mounted and polished so that microstructures can be observed. Finally, the group finds the correlation between strength and microstructures.

\section{Materials and Methods}

\subsection{Materials}

In this project, only Grade 2 and Grade 5 were used. Grade 2 represents unalloyed titanium, standard oxygen, while Grade 5 is also known as Ti6Al4V, which is the most commonly used alloy. For Grade 2, the beta transus temperature would be $913^{\circ} \mathrm{C}$ while it would be $980^{\circ} \mathrm{C}$ for Grade $5[13,14]$.

\subsection{Methods}

All heat-treated samples were first tensile tested, then polished and investigated under optical microscope. Afterwards, hardness test was conducted. The specific experimental procedures were as follows:

\subsubsection{Tensile Testing}

The dimensions of the samples were measured, and one side of the sample was colored in with marker. Laser tape was then 
added so the laser could measure the elongation in the region between the tape. The samples were loaded in the MTS 810 load frame, and they were subject to a strain rate of $2 \mathrm{~mm} / \mathrm{min}$.

\subsubsection{Mounting/Polishing}

The samples were cut using an abrasive saw, and then they were mounted in conductive bakelite. The samples were polished from 240-600 grit paper and 6-.05 $\mu \mathrm{m}$ alumina.

\subsubsection{Optical Microscopy}

The samples were etched using a Kroll's reagent (6\% nitric acid, $2 \%$ hydrofluoric acid, $92 \%$ water) and imaged at 100 , 200, and 1000x magnification. All of the imaging was done using PAXit.

\subsubsection{Hardness Testing}

The machine was used to measure macrohardness of the samples. Since titanium Grade 5 is harder than Grade 2, Grade 5 was measured on the Rockwell C scale using a 1/16 steel ball indenter and a load of $100 \mathrm{kgf}$, and Grade 2 was measured on the Rockwell B scale using a pyramidal diamond indenter and a load of $150 \mathrm{~kg}$. After these measurements were taken, the hardness values were converted to the Vicker's scale for comparison.

\section{Results}

The effects of different alpha grain composition are caused by different treated temperature on the strength of Grade 2 titanium alloys. Data from (Figures 3-5) shows the strength of Grade 2 titanium alloys at different temperature treatment and their respective microstructure under optical microscope. From the micrographs, when the Grade $2 \mathrm{Ti}$ is heat treated for 10 minutes at $680^{\circ} \mathrm{C}$, a fully equiaxed alpha grain structure is formed (Figures 3-5). These equiaxed alpha grain can be seen to have secondary alpha laths that have formed inside the grain boundaries. The secondary alpha laths are in a colony microstructure. For the heat treatment at $850^{\circ} \mathrm{C}$, the grain size of the equiaxed alpha became marginally larger and the density of secondary alpha laths had increased. The effects of the increase in alpha laths density can be seen by the higher strength of samples heat treated at $850^{\circ} \mathrm{C}$ compared to those heat treated at $680^{\circ} \mathrm{C}$. The Grade $2 \mathrm{Ti}$ heat treated at $1000^{\circ} \mathrm{C}$ shows a different microstructure than those heat treated at lower temperatures. When treated at $913^{\circ} \mathrm{C}$, the beta transus for Grade $2 \mathrm{Ti}$ is well. The treatment itself, only being 10 minutes long, allows little time for the recrystallization process to be completed. During the cooling of the titanium, secondary alpha laths were formed in a basketweave formation.
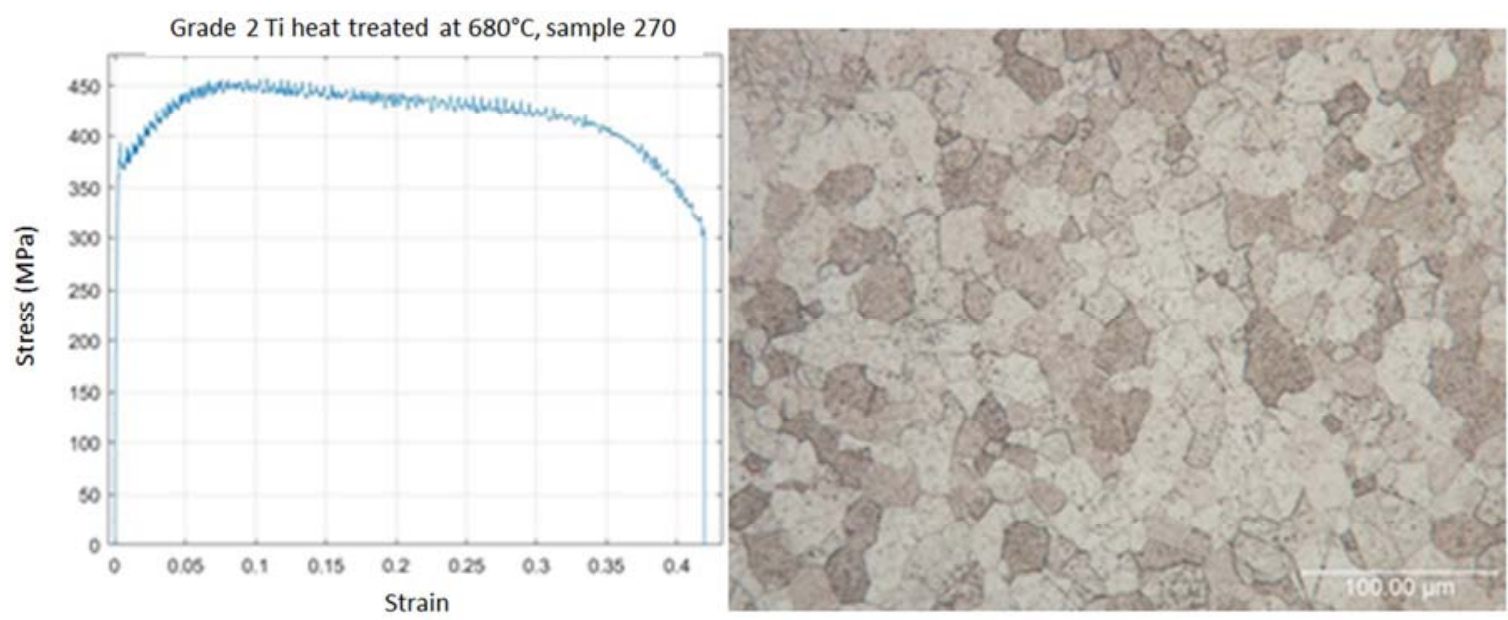

Figure 3. Stress-Strain curve and micrograph (200x) of Ti Grade 2 treated at $680^{\circ} \mathrm{C}$ for $10 \mathrm{~min}$.

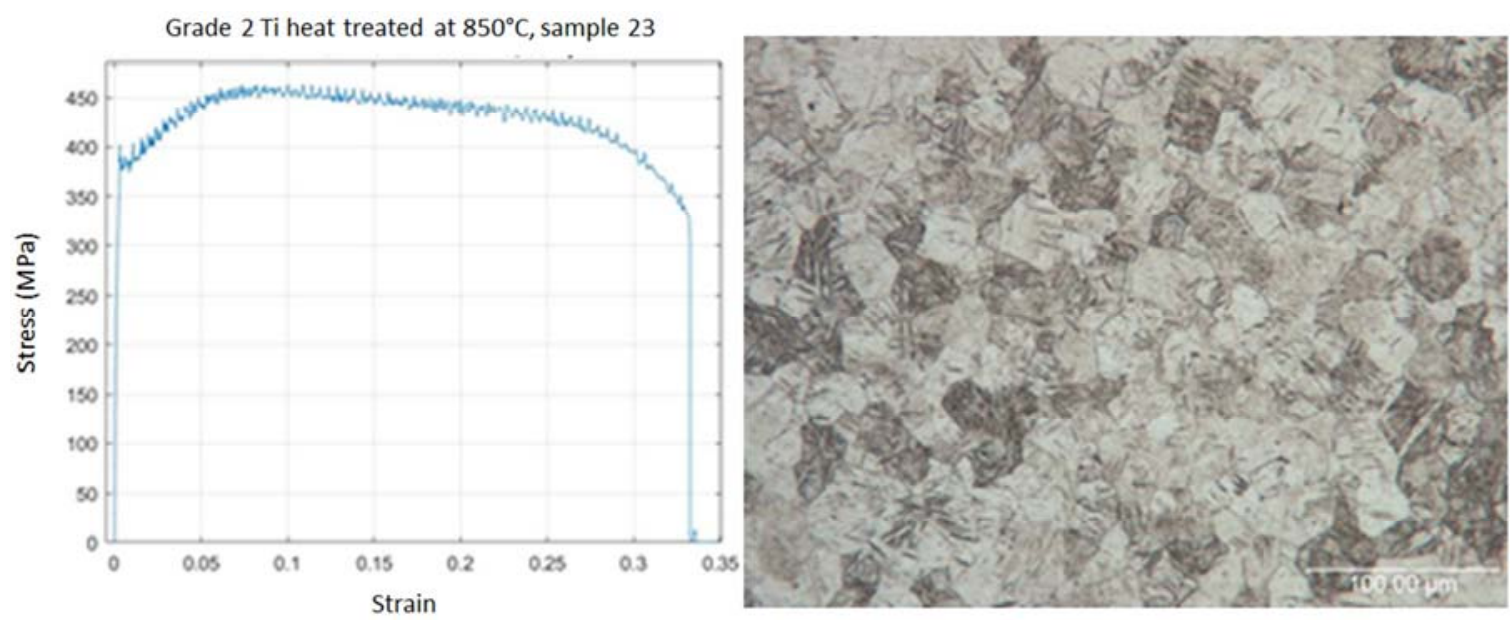

Figure 4. Stress-Strain curve and micrograph (200x) of Ti Grade 2 treated at $850^{\circ} \mathrm{C}$ for $10 \mathrm{~min}$. 


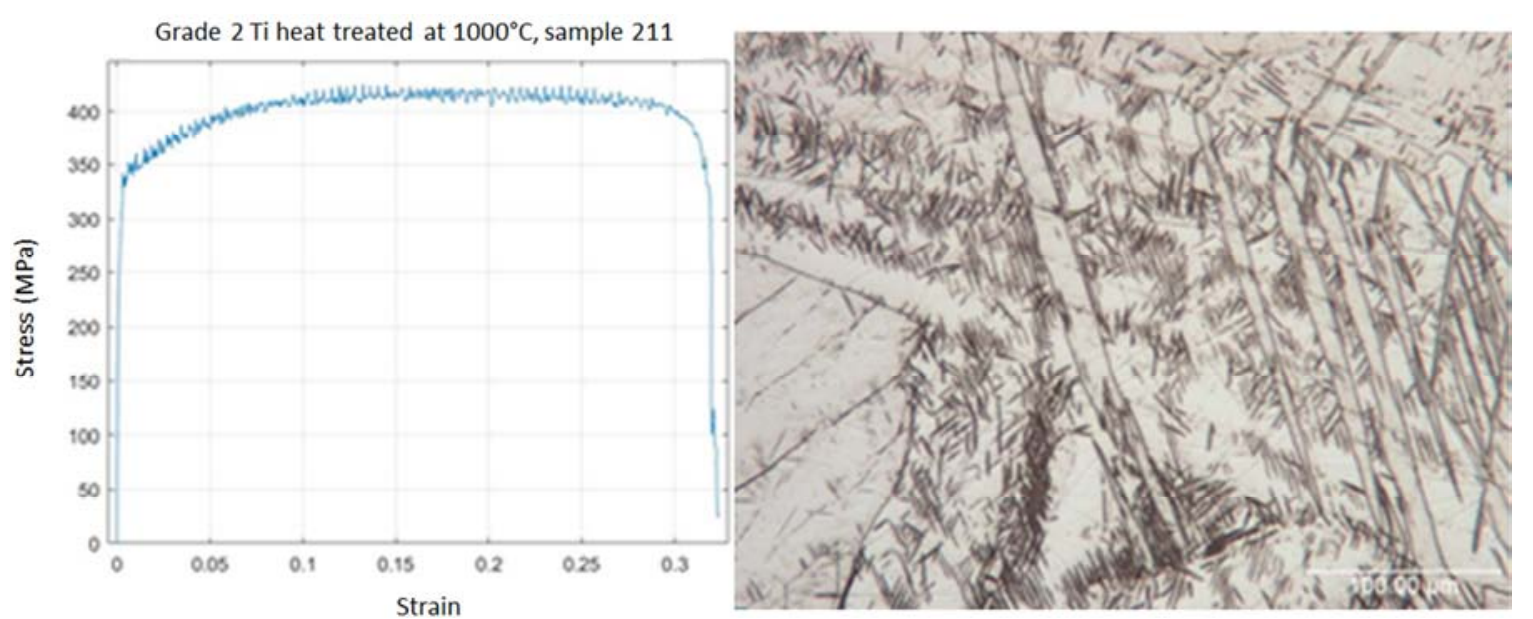

Figure 5. Stress-Strain curve and micrograph (200x) of Ti Grade 2 treated at $1000^{\circ} \mathrm{C}$ for $10 \mathrm{~min}$.

The further analysis on alpha and basketweave laths composition was conducted. Grade 2 titanium alloys at different temperature of treatment were investigated under 1000x magnification (Figure 6). For Grade 2 Ti heat treated at $680^{\circ} \mathrm{C}$, some of the grains contained alpha laths in a colony formation. When heat treated at $850^{\circ} \mathrm{C}$ there were a larger number of grains containing these alpha laths and the basketweave laths formation was also observable. The large grain size caused by the $1000^{\circ} \mathrm{C}$ heat treatment could be observed, where the average grain size increases $572 \%$ compared to that of $850^{\circ} \mathrm{C}$.

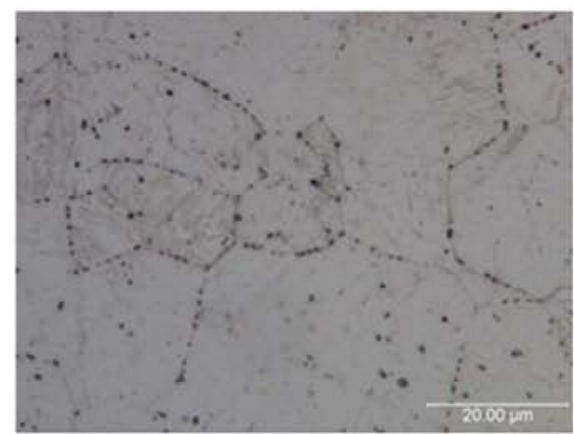

A)

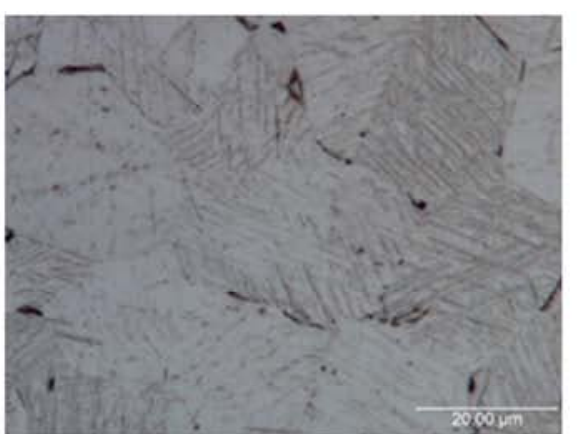

B)

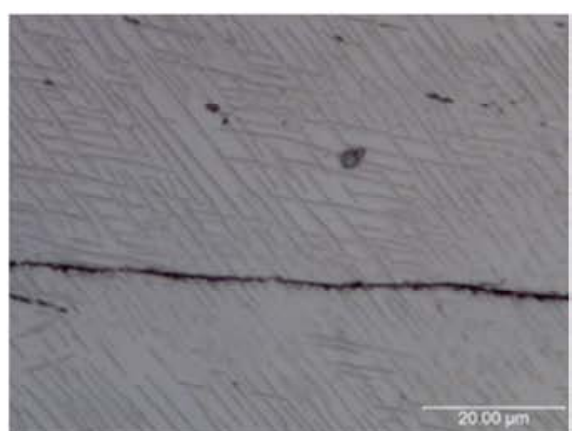

C)

Figure 6. Micrographs of Ti Grade 2 treated at (A) 680, (B) 850, and (C) $1000^{\circ} \mathrm{C}$ at $1000 x$.

The mechanical properties comparison at different brazing temperature can be seen in Figure 7. The properties of Ti Grade 2 change as heat-treatment temperature increases as shown. Upon heating, the ultimate tensile strength and yield strength decreases. The As-received strengths are highest, with UTS of $525 \mathrm{MPa}$ and a yield strength of $452 \mathrm{MPa}$. There is then a $12.7 \%$ drop of strength from the as-received to $800^{\circ} \mathrm{C}$. This is believed due to annealing at this temperature, reducing residual stresses of the as-received sample. Past $800^{\circ} \mathrm{C}$ there is an increase in strength. This is attributed to the formation of secondary alpha lath. The strength then peaks at around $850^{\circ} \mathrm{C}$ at $88 \%$ of the as-received strength; here the basketweave lath formation can be seen. Past $900^{\circ} \mathrm{C}$, the strength plateaus at about $80 \%$ of the as-received strength. There is an extreme growth in grain size that is seen at these temperatures shown at Figure 8, tabulates the data shown in Table 1.

Table 1. Ti Grade 2 Ultimate Tensile Strength, Yield Strength, Elongation, and Hardness Data.

\begin{tabular}{|c|c|c|c|c|c|c|c|c|}
\hline $\begin{array}{l}\text { Temperature } \\
\left({ }^{\circ} \mathrm{C}\right)\end{array}$ & UTS (MPa) & $\begin{array}{l}\text { UTS } \\
\text { Average }\end{array}$ & YS (MPa) & YS Average & $\begin{array}{l}\text { Elongation } \\
(\%)\end{array}$ & $\begin{array}{l}\text { Elongation } \\
\text { Average }\end{array}$ & $\begin{array}{l}\text { Hardness } \\
\text { (Vickers) }\end{array}$ & $\begin{array}{l}\text { Hardness } \\
\text { Average }\end{array}$ \\
\hline 680 & 456.7 & \multirow{2}{*}{471.7} & 371.7 & \multirow{2}{*}{347.7} & 42.0 & \multirow{2}{*}{37.0} & 152.0 & \multirow{2}{*}{153.5} \\
\hline 680 & 486.6 & & 323.8 & & 32.0 & & 155.0 & \\
\hline 850 & 463.0 & \multirow{2}{*}{462.0} & 381.7 & \multirow{2}{*}{376.0} & 33.3 & \multirow{2}{*}{35.6} & 155.0 & \multirow{2}{*}{153.5} \\
\hline 850 & 461.0 & & 370.4 & & 37.9 & & 152.0 & \\
\hline 900 & 450.1 & \multirow{2}{*}{445.9} & 368.2 & \multirow{2}{*}{362.2} & 35.1 & \multirow{2}{*}{35.4} & 150.0 & \multirow{2}{*}{149.5} \\
\hline 900 & 441.7 & & 356.1 & & 35.8 & & 149.0 & \\
\hline 950 & 416.9 & \multirow{2}{*}{416.6} & 328.6 & \multirow{2}{*}{326.2} & 32.5 & \multirow{2}{*}{32.7} & 139.0 & \multirow{2}{*}{133.0} \\
\hline 950 & 416.3 & & 323.7 & & 32.9 & & 127.0 & \\
\hline 1000 & 424.6 & \multirow{2}{*}{418.8} & 330.8 & \multirow{2}{*}{333.2} & 31.9 & \multirow{2}{*}{33.3} & 138.0 & \multirow{2}{*}{131.5} \\
\hline 1000 & 413.0 & & 335.5 & & 34.6 & & 125.0 & \\
\hline
\end{tabular}




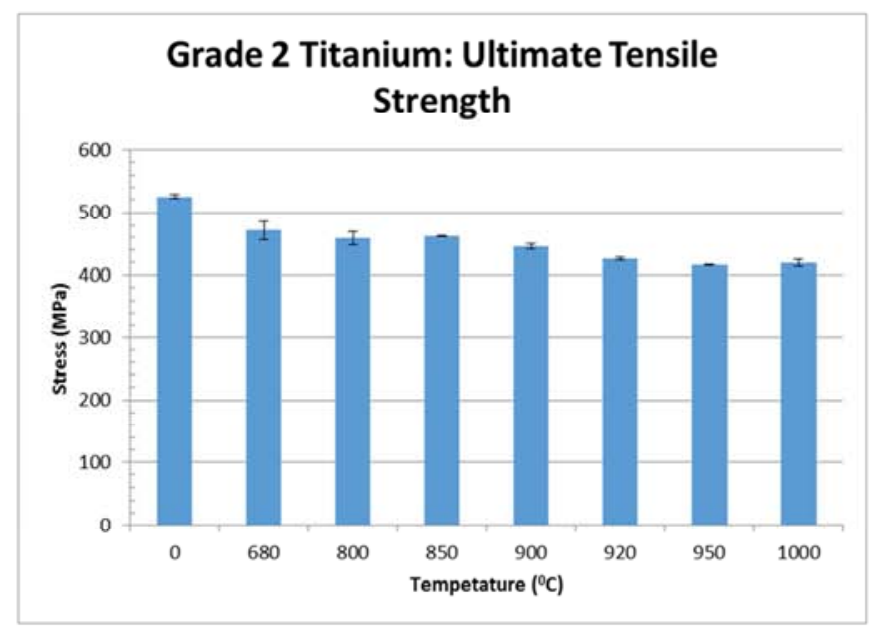

A)

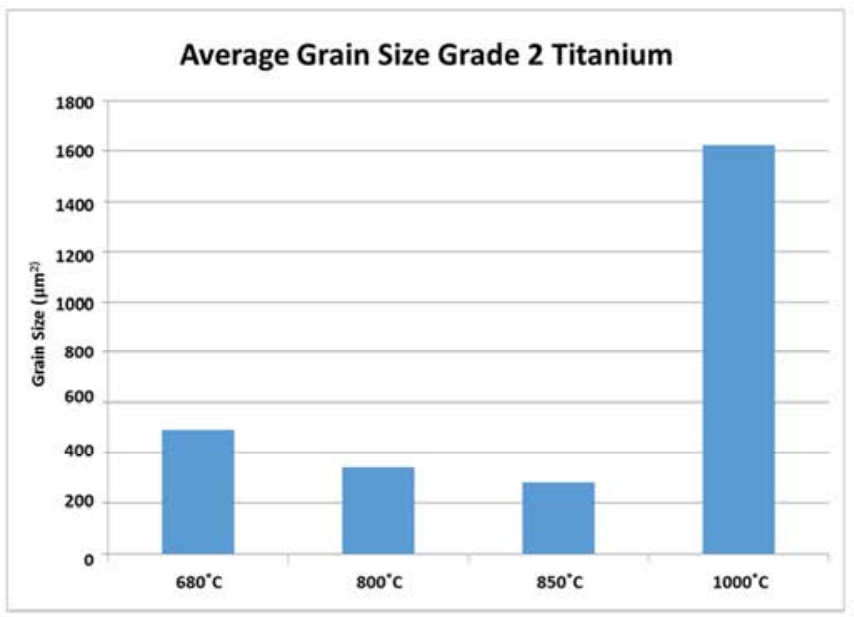

C)

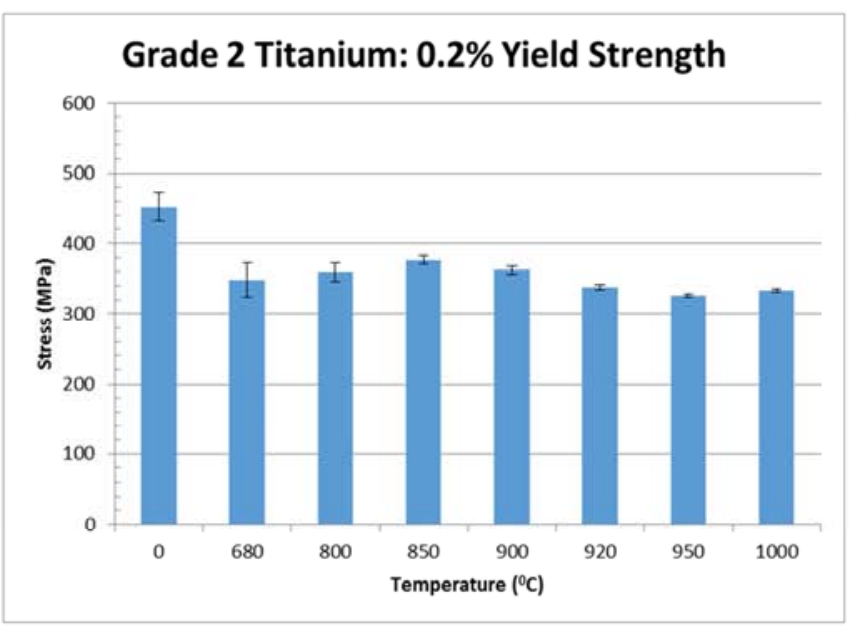

B)

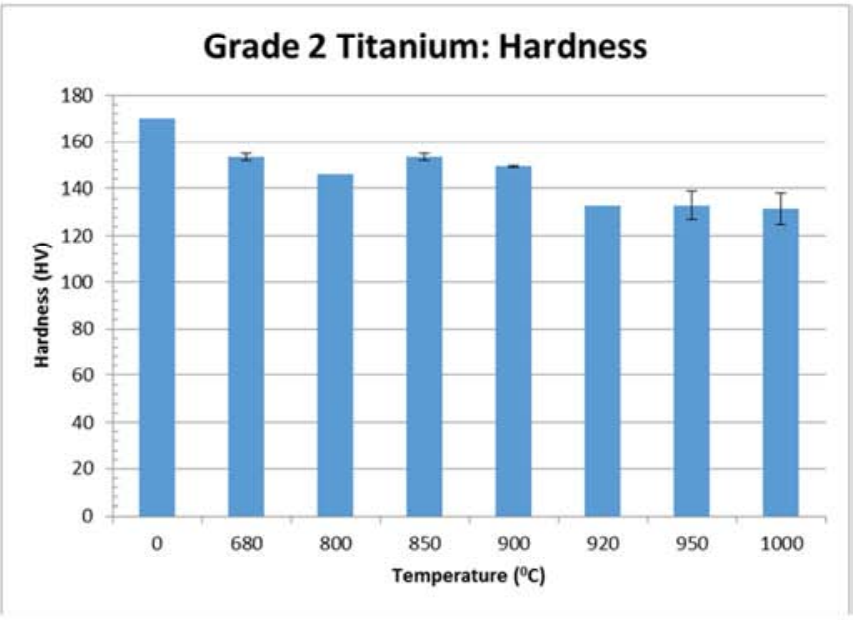

D)

Figure 7. Ti Grade 2 (A) Ultimate Tensile Strength, (B) Yield Strength, (C) Grain Size, and (D) Hardness Graphs.

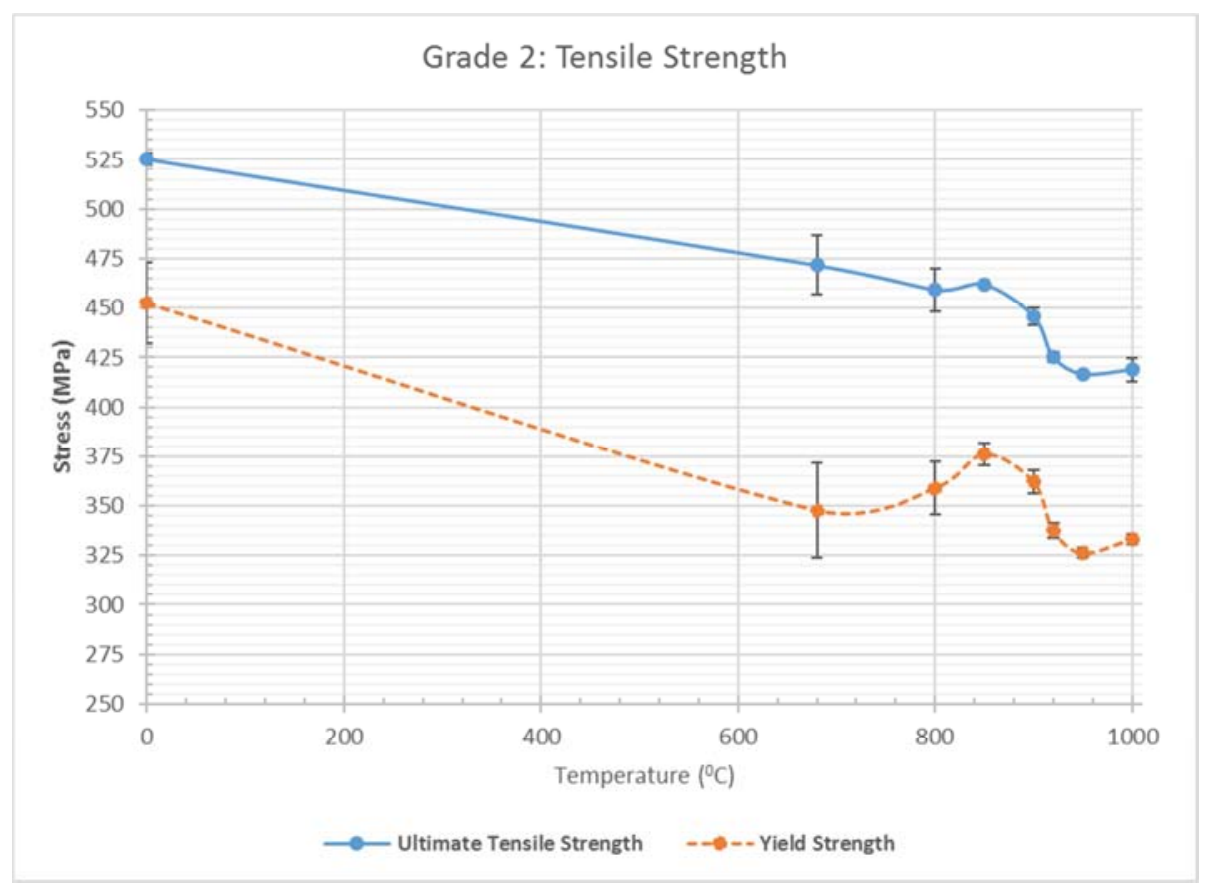

Figure 8. Ti Grade 2 Ultimate Tensile Strength and Yield Strength. 
The effects of fully equiaxed alpha with intergranular beta grain structure are caused by different treated temperature on mechanical strength of Grade 5 titanium alloys. The strength of Grade 5 titanium alloys at different temperature treatment and their respective microstructure under optical microscope are shown (Figures 9-11). From the micrographs, when the
Grade $5 \mathrm{Ti}$ is heat treated for 10 minutes at $680^{\circ} \mathrm{C}$, a fully equiaxed alpha with intergranular beta grain structure is formed. For the heat treatment at $850^{\circ} \mathrm{C}$, the equiaxed alpha with intergranular beta grains have coarsened. In the micrograph for the $1000^{\circ} \mathrm{C}$ heat treatment, acicular alpha and intergranular beta can be seen to have formed.
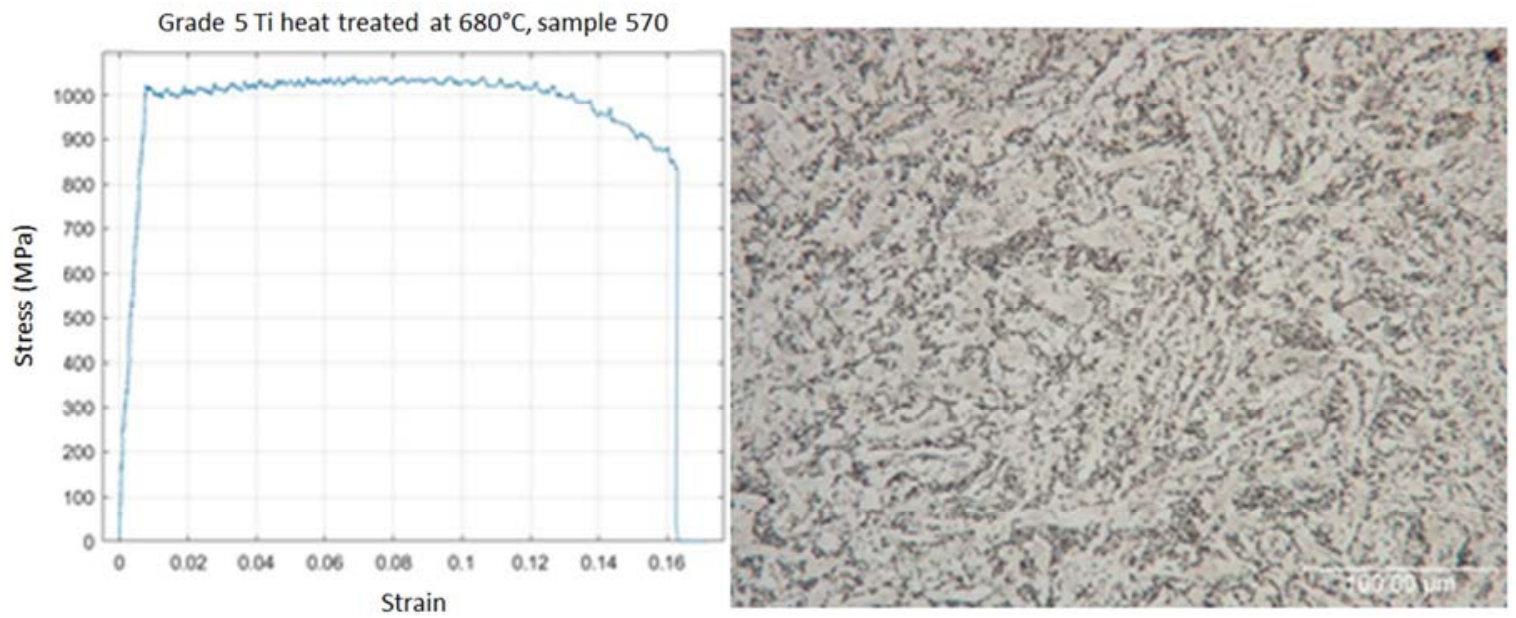

Figure 9. Ti Grade 2 Ultimate Tensile Strength and Yield Strength.

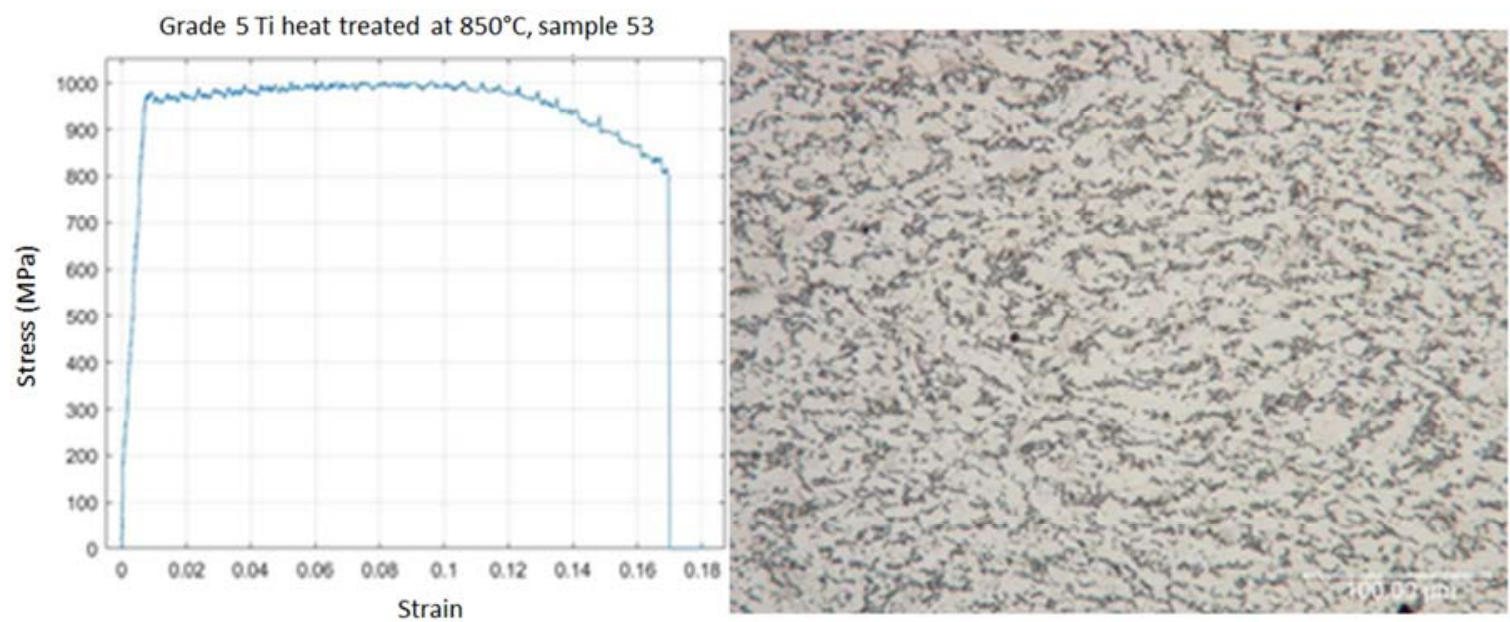

Figure 10. Stress-Strain curve and micrograph (200x) of Ti Grade 5 treated at $850^{\circ} \mathrm{C}$ for $10 \mathrm{~min}$.

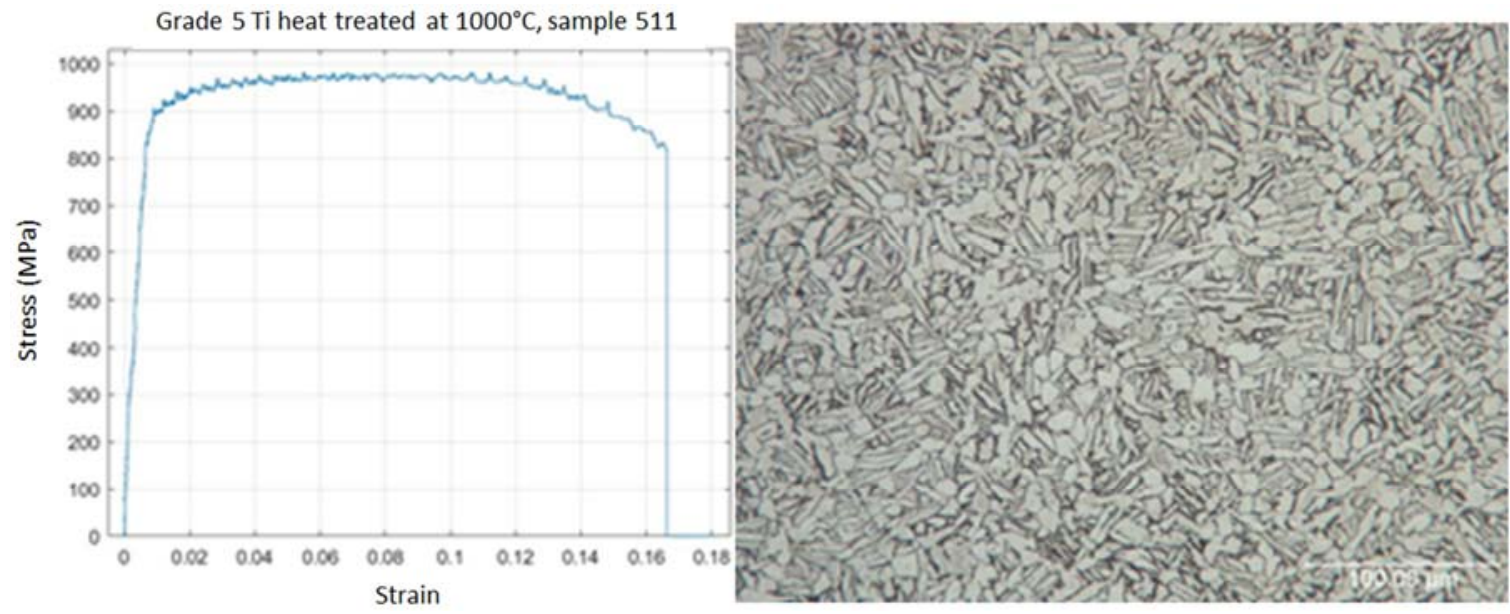

Figure 11. Stress-Strain curve and micrograph (200x) of Ti Grade 5 treated at $1000^{\circ} \mathrm{C}$ for $10 \mathrm{~min}$. 
The Beta and alpha grain concentration were further investigated at a magnification of 1000x (Figure 12). The fully equiaxed alpha with intergranular beta grain structure can be seen in both samples from $680^{\circ} \mathrm{C}$ and $850^{\circ} \mathrm{C}$ heat treatment. It is also seen that there is some acicular alpha that is starting to form in the $850^{\circ} \mathrm{C}$ heat treatment sample. The samples heat treated at $1000^{\circ} \mathrm{C}$ can be seen to have a fully acicular alpha and intergranular beta microstructure.

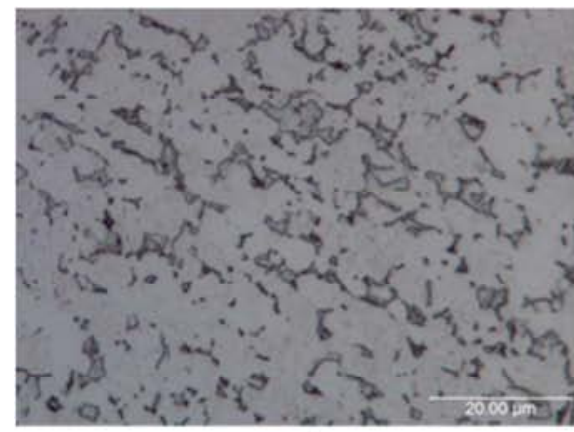

A)

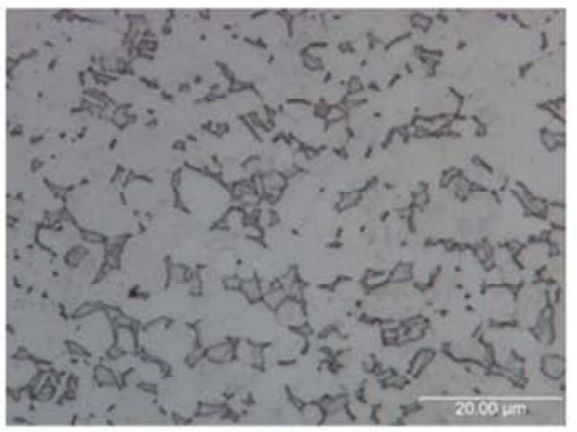

B)

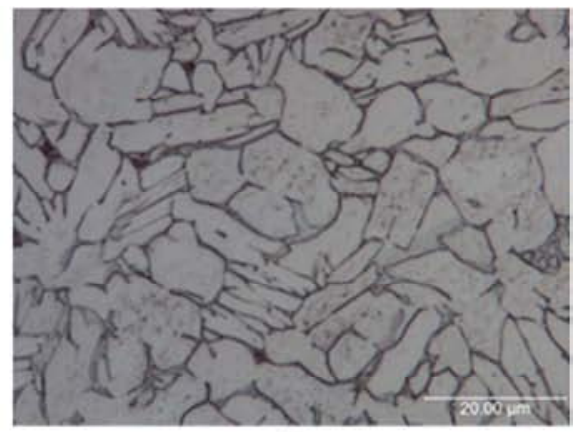

C)

Figure 12. Micrographs of Ti Grade 5 treated at (A) 680, (B) 850, and (C) $1000^{\circ} \mathrm{C}$ at $1000 x$.

The change in properties of Ti Grade 5 subjected to varying heat-treatments is reflected in Figure 13. The ultimate tensile strength and yield strength follows a similar trend (Figure 14). The As-received sample has the highest ultimate tensile strength with a value of $1051.6 \mathrm{MPa}$ and yield strength of 1013.8 MPa. However, for ultimate strength curve, it is noticed that the value is stable at $1000 \mathrm{MPa}$ between

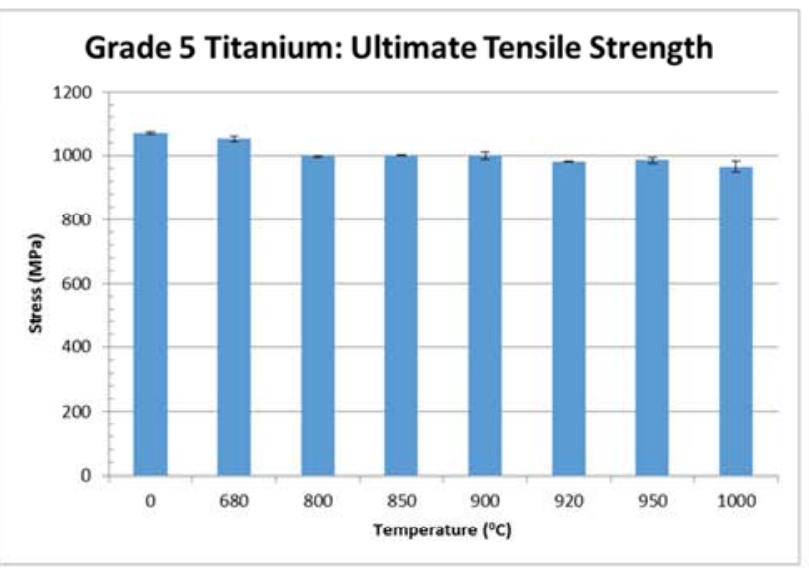

A)

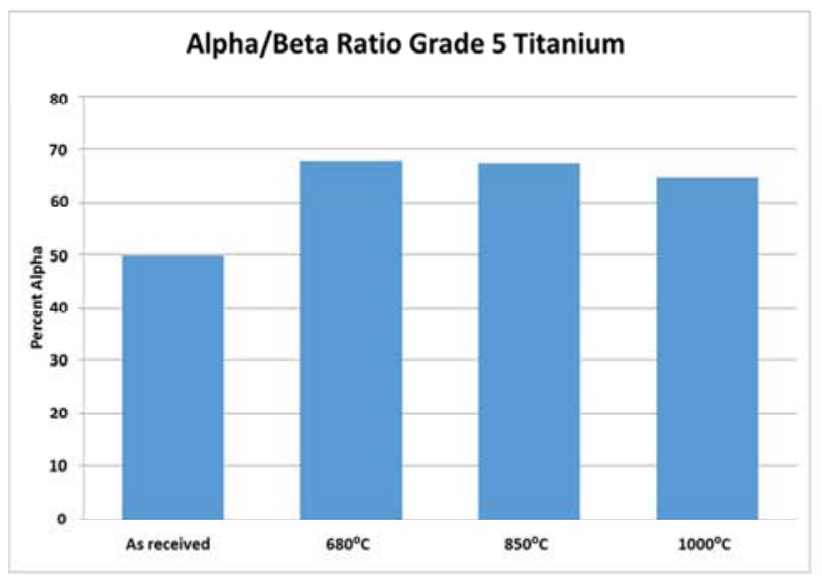

C) $850^{\circ} \mathrm{C}-900^{\circ} \mathrm{C}$. The hardness has a drastic increase with the initial temperature increase, and it steadily decreases above $680^{\circ} \mathrm{C}$ as grain size getting larger at elevated temperature. Table 2 shows the data from Ti Grade 5 (A) Ultimate Tensile Strength, (B) Yield Strength, (C) Alpha/Beta, and (D) Hardness in a numerical manner.

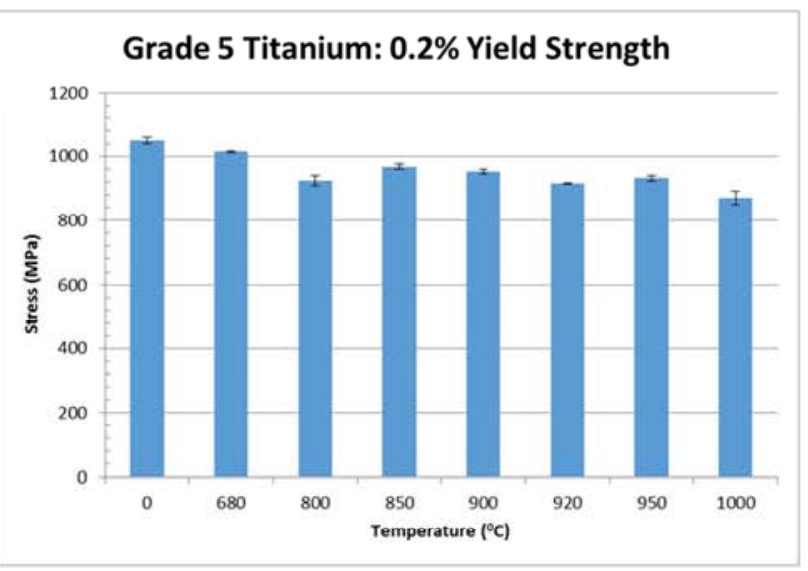

B)

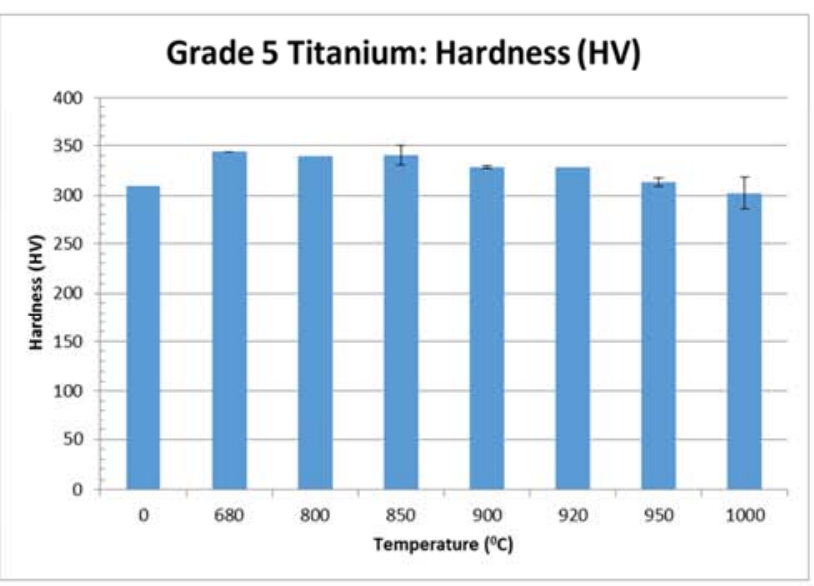

D)

Figure 13. Ti Grade 5 (A) Ultimate Tensile Strength, (B) Yield Strength, (C) Alpha/Beta, and (D) Hardness Graphs. 


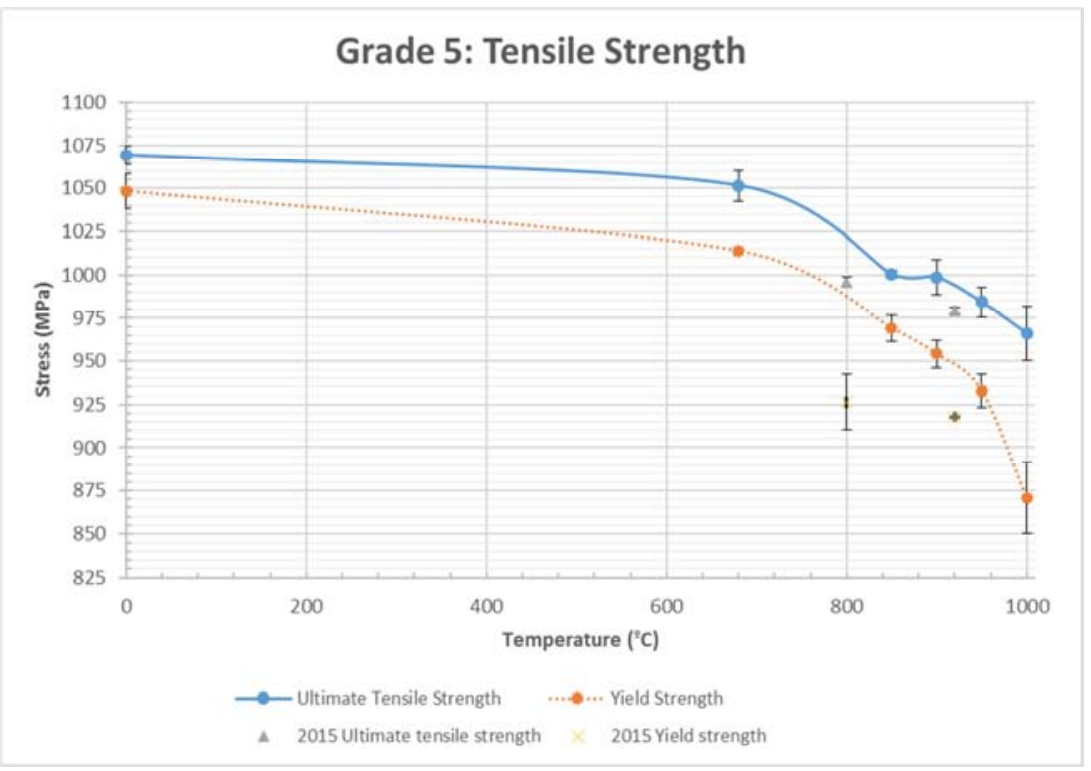

Figure 14. Ti Grade 5 Ultimate Tensile Strength and Yield Strength.

Table 2. Ti Grade 5 Ultimate Tensile Strength, Yield Strength, Elongation, and Hardness Data.

\begin{tabular}{|c|c|c|c|c|c|c|c|c|}
\hline $\begin{array}{l}\text { Temperature } \\
\left({ }^{\circ} \mathrm{C}\right)\end{array}$ & $\begin{array}{l}\text { UTS } \\
\text { (MPa) }\end{array}$ & $\begin{array}{l}\text { UTS } \\
\text { Average }\end{array}$ & $\begin{array}{l}\text { YS } \\
\text { (MPa) }\end{array}$ & $\begin{array}{l}\text { YS } \\
\text { Average }\end{array}$ & Elongation (\%) & $\begin{array}{l}\text { Elongation } \\
\text { Average }\end{array}$ & Hardness (Vickers) & $\begin{array}{l}\text { Hardness } \\
\text { Average }\end{array}$ \\
\hline 680 & 1042.7 & \multirow{2}{*}{1051.6} & 1016.0 & \multirow{2}{*}{1013.8} & 16.3 & \multirow{2}{*}{15.8} & 344.0 & \multirow{2}{*}{344.0} \\
\hline 680 & 1060.4 & & 1011.6 & & 15.4 & & 344.0 & \\
\hline 850 & 1002.5 & \multirow{2}{*}{1000.5} & 976.8 & \multirow{2}{*}{969.2} & 17.0 & \multirow{2}{*}{16.7} & 331.0 & \multirow{2}{*}{340.5} \\
\hline 850 & 998.5 & & 961.6 & & 16.4 & & 350.0 & \\
\hline 900 & 988.5 & \multirow{2}{*}{996.7} & 946.2 & \multirow{2}{*}{954.2} & 16.9 & \multirow{2}{*}{16.5} & 327.0 & \multirow{2}{*}{328.5} \\
\hline 900 & 1008.8 & & 962.1 & & 16.0 & & 330.0 & \\
\hline 950 & 992.9 & \multirow{2}{*}{984.4} & 942.6 & \multirow{2}{*}{933.0} & 16.3 & \multirow{2}{*}{16.4} & 309.0 & \multirow{2}{*}{313.5} \\
\hline 950 & 975.8 & & 923.3 & & 16.5 & & 318.0 & \\
\hline 1000 & 981.9 & \multirow{2}{*}{966.2} & 891.7 & \multirow{2}{*}{870.9} & 16.6 & \multirow{2}{*}{15.5} & 319.0 & \multirow{2}{*}{302.5} \\
\hline 1000 & 950.5 & & 850.1 & & 14.4 & & 286.0 & \\
\hline
\end{tabular}

\section{Discussion}

Acicular alpha is when there is a high-volume fraction of primary alpha that the alpha grains start to interconnect [15]. It is suggested that the formation of acicular alpha is the cause for the decrease in strength when compared to other heat treatments.

In this project experiment, the beta transus for Grade $2 \mathrm{Ti}$ was well below the $1000^{\circ} \mathrm{C}$ heat treatment in 10 minutes and little time for the recrystallization process was allows to be completed. Ultimately, the titanium was cooled during this recrystallization process causing it to form extremely large primary alpha grains. During the cooling, secondary alpha laths were formed in a basketweave formation. The large increase in primary alpha grain size is seen to have a negative effect on the strength of the titanium.

Regarding the Grade 5 titanium alloys, the coarsening is a suggested reason as to why there was a decrease in strength, when compared to the $680^{\circ} \mathrm{C}$ heat treatment. The As-received sample had the highest ultimate tensile strength and yield strength. Generally, they both decrease with an increase in temperature and can be explained by the same theory as mentioned for Ti Grade 2. It is still unsure that the exact reason of the value is stable at $1000 \mathrm{MPa}$ between $850^{\circ} \mathrm{C}-900^{\circ} \mathrm{C}$. The group determines that it can be resulted from grain size and alpha percentage change. Nevertheless, the reason for the jump is unsure as well and more data points falling in that region seem needed.

In the current research, the group didn't see much of change in alpha/beta ratio. Therefore, the exact reason for decreasing strength is unknown. If the group applies EBSD analysis on Titanium Grade 5 alloys, the average alpha grain size in the Titanium Grade 5 samples can be determined. Therefore, the reason behind strength decreasing can be better discussed. Also, the samples in current experiment were all heat treated for 10 minutes. If the group changes the brazing processing time, such as 30 seconds, the mechanical properties of samples treated in much shorter time could be determined. Furthermore, other brazing processes can also be explored such as thermal cycles using induction brazing or torch brazing. In that case, the effect of different brazing methods on Titanium samples could be seen.

\section{Conclusion}

Titanium alloys are widely utilized in industrial world because of its promising mechanical properties. Thus, it can 
be applied in aircraft frame, blade, vessel and so on. In this study, The effect of brazing on Grade 2 and Grade 5 titanium alloys were determined and the microstructures and mechanical properties of them after brazing were investigated by microscopy, tensile test. There was a very significant relationship between microstructures and mechanical properties because mechanical properties are normally determined by corresponding microstructures. Through our study, for the Titanium Grade 2 samples, the initial drop in strength is due to annealing. Around $800^{\circ} \mathrm{C}$, alpha laths begin forming, and the strength begin increasing. The strength peaked at $850^{\circ} \mathrm{C}$ where the basketweave alpha laths are formed. Above that temperature, the grains sizes grew significantly which reflect a decrease in strength. For the Titanium Grade 5 samples, there is not much of a change in the alpha/beta ratio, so the decrease in strength cannot stem from that. It is expected to root from the increasing alpha grain size.

Controlling brazing temperature is a relatively easy way to control the microstructures of materials and doesn't need additional steps or processing which could potentially mess up the materials themselves because of potential unprofessional operation. Also, brazing treatment is not a complicated method and can be very easily done in industry and factory. Moreover, it is considered to be an economic method because less steps and processing are involved. Based on this study, people could produce titanium alloys with desired properties according to the requirement of performance.

\section{Acknowledgements}

This research used all of titanium alloys provided by Dr. Alex Shapiro.

\section{References}

[1] Shapiro, Alex. "Capstone Introduction.” Titanium Brazing, Inc.

[2] Schwartz, Mel M. (1987). Brazing. ASM International. ISBN 978-0-87170-246-3. pp. 131-160.
[3] Schwartz, Mel M. (1987). Brazing. ASM International. ISBN 978-0-87170-246-3. pp. 163-185.

[4] 2004, W. B. (2018, August 21). Titanium Alloys Characterstics of Alpha, Alpha Beta and Beta Titanium Alloys. Retrieved July 20, 2019, from https://www.azom.com/article.aspx?ArticleID=2591

[5] Titanium - A Technical Guide. ASM International. 2000. ISBN 9781615030620 .

[6] R. Boyer, G. Welsch, and E. W. Collings, eds. Materials Properties Handbook: Titanium Alloys, ASM International, Materials Park, OH, 1994.

[7] 6AL-4V Titanium. (n.d.). Retrieved July 20, 2019, from https://performancetitanium.com/6al-4v-grade5/

[8] Mandal S., Ray, A. K., \& Ray, A. K. Correlation between the mechanical properties and the microstructural behaviour of $\mathrm{Al}_{2} \mathrm{O}_{3}-(\mathrm{Ag}-\mathrm{Cu}-\mathrm{Ti})$ brazed joints. Materials Science and Engineering: A, 2004, vol. 383 (2), pp. 235-244.

[9] Wang R. R., \& Welsch, G. E. Joining titanium materials with tungsten inert gas welding, laser welding, and infrared brazing. The Journal of prosthetic dentistry, 1995, vol. 74 (5), pp. 521-530.

[10] Botstein O., \& Rabinkin A. Brazing of titanium-based alloys with amorphous $25 \mathrm{wt} . \%$ Ti-25wt.\% Zr-50wt.\% Cu filler metal. Materials Science and Engineering: A, 1994, vol. 188 (1-2), pp. 305-315.

[11] Shujie Pang, Lulu Sun, Huaping Xiong, Chen Chen, Ying Liu, Haifei Li, Tao Zhang. A multicomponent TiZr-based amorphous brazing filler metal for high-strength joining of titanium alloy [J]. Scripta Materialia, 2016, vol. 117, pp. 55-59.

[12] A. Winiowski, D. Majewski. Brazing of Titanium with Aluminium Alloys [J]. Archives of Metallurgy and Materials, 2017, vol. 62 (2), pp. 763-770.

[13] Aerospace Specification Metals, Inc. "Titanium Grade 2." asm.matweb.com

[14] Aerospace Specification Metals, Inc. "Titanium Grade 5." asm.matweb.com

[15] Lütjering G., J. C. Williams. Titanium. 2nd ed. Berlin: Springer, 2003. Print. 